\title{
単独水制周辺部の浅水流可視化実験と組織的流れ構造の移流過程
}

門田 章宏 ${ }^{\circ}$ (愛媛大学), 鈴木幸一(愛媛大学)

\section{Shallow Flow Visualization around a Single Groyne and the Advection of Coherent Structures}

\author{
Akihiro KADOTA and Koichi SUZUKI
}

\begin{abstract}
Groynes have been used for stabilization of banks and creating navigation channel by confining cross section, especially for large European and Japanese rivers. Therefore, studies on 2D shallow flows and transport phenomena in groyne field have paid attention to the proper environment for ecosystem and suitable design for bank protection and obtainment of enough depth of main channel.

Typical Japan-river characteristics are large variation of discharge due to big amount of rainfalls so that the groynes are affected by the instantaneous and coherent flows with high energy. Therefore, present study focuses the effects of instantaneous and coherent flow structures around a single groyne by means of a technique of shallow flow visualization and particle tracking velocimetry applied for the large velocity differences. In addition, the advection of coherent structures around the groyne are analyzed and discussed by means of POD decomposition and conditional sampling method.

Keywords: PTV, proper orthogonal decomposition (POD), conditional sampling analysis
\end{abstract}

\section{1. 緒 論}

河川の境界に存在する水制構造物は様々な役割を持ち, ヨーロッパ諸国では主に貨物船等の航行に必要な航路の 確保に水制が使われている，その他，日本の河川では護 岸や水生生物にとっての器境改善の目的でも用いられて いる. また, 日本の主な気象・河川特性として挙げられ るのは, 降雨量の季節的変動が大きく, 流路が短く急峻 であることである。近年観察される様々な自然現象は， 温暖化による影響と併せて, 突発的な豪雨·洪水が多く， 水制等の河川構造物周辺の流れは瞬間的に大きなエネル ギーを持つ流れが支配的となり, 従来研究が行われてい る洗掘等の物質輸送現象の解明の基本情報となった平均 流的な流れとは大きく異なる，以上の様な背景により， 本研究では河川構造物周辺の流れの中でも, 組織的でか つ瞬間的な流れの局所的な場に及ぼす影響がむしろ重要 であるといら観点から，河川水制周辺の二次元浅水流の 瞬間的に発生する組織的流れの構造を浅水流可視化実験 により解明した。

\section{2. 実験方法および条件}

本研究では, ドイツ・カールスルーエ大学水力学研究 所に設置された水路幅 $5.5 \mathrm{~m}$, 水路長 $13.5 \mathrm{~m}$ の広幅開水路 を用い, 水制周りの浅水流を発生させ可視化実験を行っ

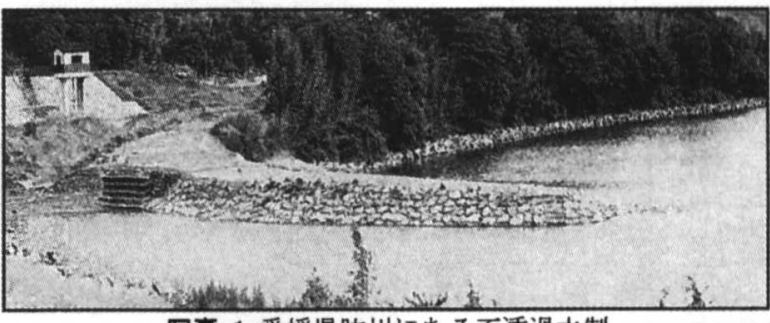

写真-1 愛媛県肱川にある不透過水制

た。また水路周辺には画像撮影用のデジタルカメラ (PhotonfocusMV-D 1024K-28CL) とカメラを移動させる トラバース装置, トレーサ粒子供給装置と八ロゲン光源 を設置した、トレーサ粒子についてはポリプロピレン(粒 径 $2-3 \mathrm{~mm}$, 密度 $0.9 \mathrm{~g} / \mathrm{cm} 3$ )を粒子どうしの吸着を防ぐため に黒色ラッカーによるコーティングを施したものを使用 した. 水制模型については, 愛媛県にある一級河川肱川 に 17 世紀頃から存在する護岸目的の水制(写真-1)を対象 とした. 水路の大きさを考虑し約 $1 / 40$ のスケールモデル (長さ $70 \mathrm{~cm}$, 高さ $7 \mathrm{~cm}$, 底部幅 $40 \mathrm{~cm}$ )を作成した. 実験条 件については, 現地付近の水位観測所のデータから, 周 辺の流速差が最大となる非越流状態の水深 $6 \mathrm{~cm}$ の条件で 撮影を行った. また流量については流量制御装置と可視 化計測における制約を考慮して 50liter/sec とした.一方, 画像取得システムについては, 画像取得ソフトウェア 


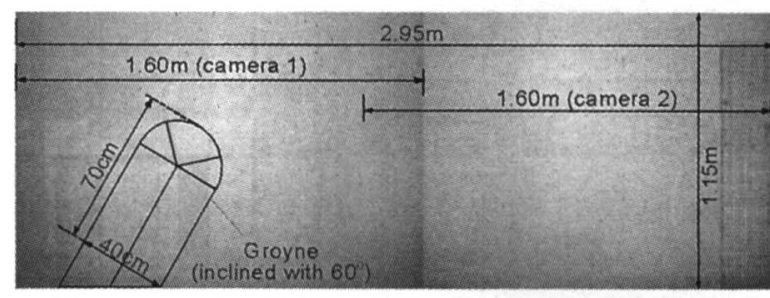

図-2２台のカメラ画像をオーバーラップさせた撮影領域

(Heurisko と Silicon Software Micro enable I)を使用した. 画像取得サイズは 1 台のカメラについて $1024 \times 768$ pixel, 測定周波数は $10 \mathrm{~Hz}$ である.このデジタルカメラについ ては, 水制先端から発達する渦が 1 台のカメラの撮影サ イズ(幅 $1.60 \mathrm{~m}$ )よりも下流側に大きく発達する現象が見 られたため 2 台同時撮影による撮影領域拡張を試みた. 撮影の際には 2 台のカメラの撮影領域を $0.25 \mathrm{~m}$ 分だけオ 一バーラップ(図-2)するようにして，下流方向の撮影サ イズを $2.95 \mathrm{~m}$ まで拡張した．また，さらに 2 台のカメラ を下流側にも移動させ同様な方法で撮影した.

\section{3. 解析方法}

本可視化画像解析では, 従来から PTV 法で用いられて いる FFT 相互相関法と直接相互相関法のそれぞれの利点 を組み合わせ, それぞれの欠点を補う手法を考え開発し た.これによって得られた瞬間流速べクトルを等間隔メ ッシュ上に補間した. また, 客観的に乱流の組織構造を 抽出するための方法として用いられている正規直交分解 法(POD 法)をこの補間した瞬間変動流速データに適用し た. さらに, POD解析によって抽出された組織的な乱れ 変動パターンの移流過程を観察する手法として, 以下の 条件付きサンプリング手法(CST 法)を採用した. CST 法 では, POD 解析から抽出された組織的乱れ変動パターン を示す領域のスペクトル解析を行うことで発生周期を求 め, これを条件として与えることで水制周辺の組織的乱 れ変動パターンの移流過程を捉えることに成功した.

\section{4. 組織的乱れ変動の移流過程に関する解析結果}

図-3 は主な平均流特性を, 図-4 は POD 解析から得ら れた乱れ変動の中で最も強いエネルギーをもつ組織的パ ターンの移流特性を条件付きサンプリング手法(CST 法) によって求め示したものである，せん断層に沿って水制 先端から流れ方向に発達する乱れ変動パターンとその移 流過程が観察できる．この大きな乱れ変動が発生する領 域では, 流砂などの大きな物質輸送が起き, 局所洗掘や 河床波発生の大きな原因となると考えられ，今後この様 な局所的で組織的な乱れ変動と物質輸送との相互作用を 考える必要がある.

\section{5. 結 論}

本研究では, 水制周辺の瞬間的・組織的構造の変化に 着目し, 浅水流可視化実験や広範囲な流速に対応できる

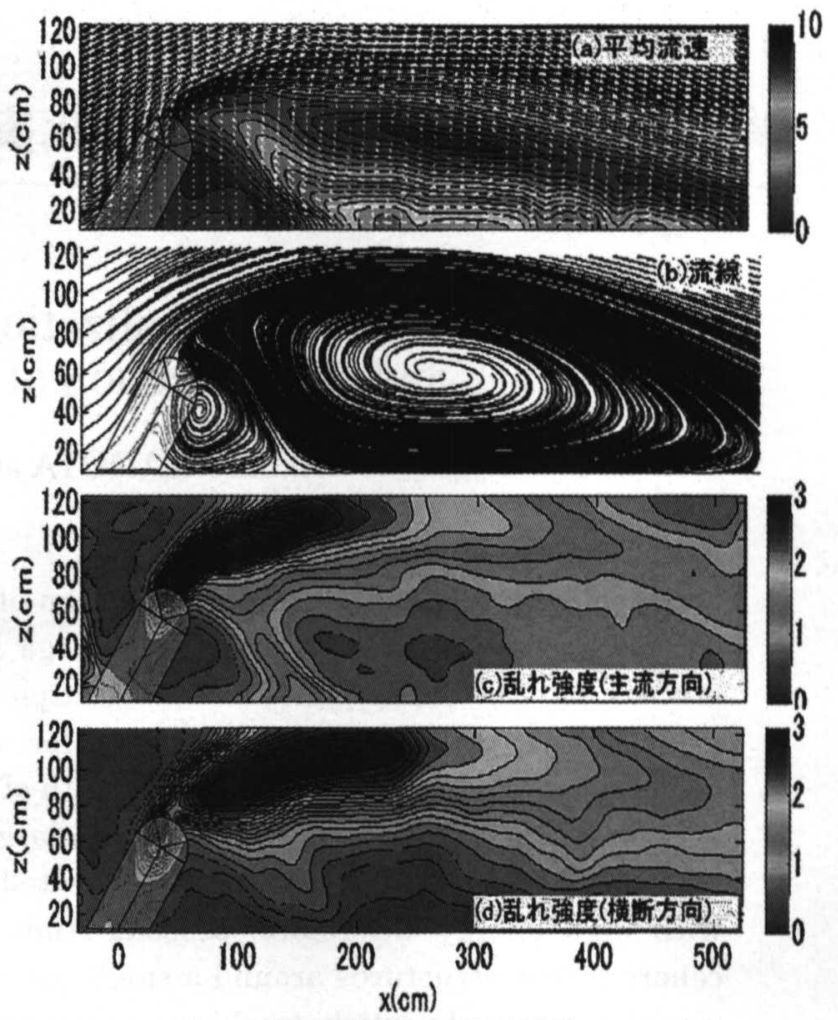

図-3 水制周辺の平均流特性
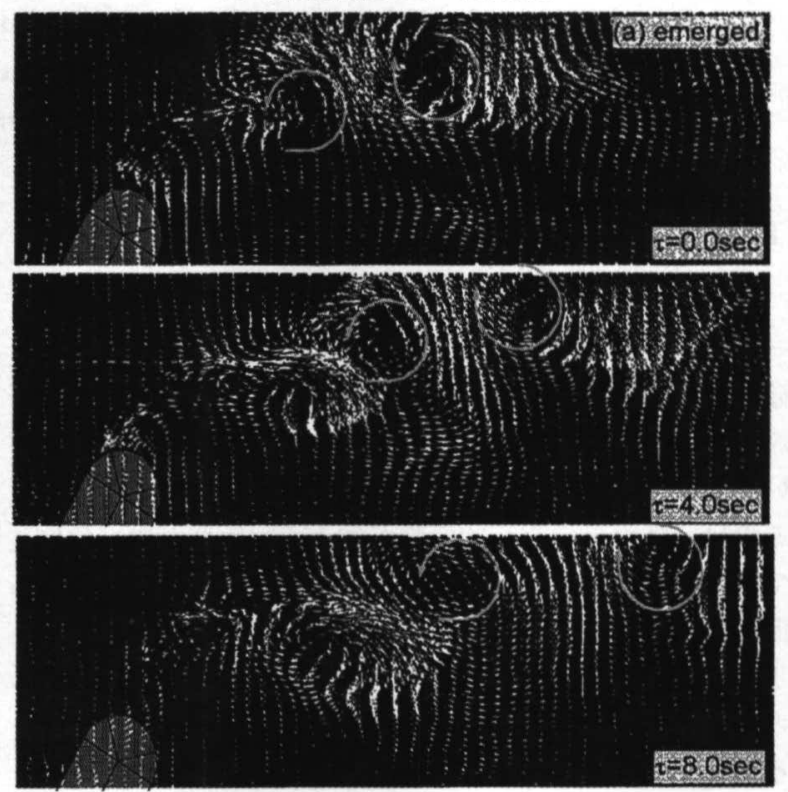

図-4 水制周辺の乱れ変動パターンと移流過程

画像粒子追跡法(PTV 法)を適用し瞬間流速を評価した. また, これらの瞬間流速データを POD 法や CST 法を適 用することで, 水制周辺に発生する特徵的な組織渦構造 を抽出し移流過程を明らかにした. これらの結果は, 卓 越するエネルギーを持つ乱れ変動場が局所的に起き, ど の様に移流するかを明らかにすることができる. 瞬間的 で局所的で乱れ変動の組織的な構造が, 全体的な流れ場 への影響だけでなく物質拡散現象などへの影響について も考虑できると考えられる. 